\title{
The electron transfer complex between nitrous oxide reductase and its electron donors
}

\author{
Simone Dell'Acqua $\cdot$ Isabel Moura $\cdot$ \\ José J. G. Moura $\cdot$ Sofia R. Pauleta
}

Received: 29 March 2011/Accepted: 20 June 2011/Published online: 8 July 2011

(C) SBIC 2011

\begin{abstract}
Identifying redox partners and the interaction surfaces is crucial for fully understanding electron flow in a respiratory chain. In this study, we focused on the interaction of nitrous oxide reductase $\left(\mathrm{N}_{2} \mathrm{OR}\right)$, which catalyzes the final step in bacterial denitrification, with its physiological electron donor, either a $c$-type cytochrome or a type 1 copper protein. The comparison between the interaction of $\mathrm{N}_{2} \mathrm{OR}$ from three different microorganisms, Pseudomonas nautica, Paracoccus denitrificans, and Achromobacter cycloclastes, with their physiological electron donors was performed through the analysis of the primary sequence alignment, electrostatic surface, and molecular docking simulations, using the bimolecular complex generation with global evaluation and ranking algorithm. The docking results were analyzed taking into account the experimental data, since the interaction is suggested to have either a hydrophobic nature, in the case of $P$. nautica $\mathrm{N}_{2} \mathrm{OR}$, or an electrostatic nature, in the case of $P$. denitrificans $\mathrm{N}_{2} \mathrm{OR}$ and $A$. cycloclastes $\mathrm{N}_{2} \mathrm{OR}$. A set of well-conserved residues on the $\mathrm{N}_{2} \mathrm{OR}$ surface were identified as being part of the electron transfer pathway from the redox partner to $\mathrm{N}_{2} \mathrm{OR}$ (Ala495, Asp519, Val524, His566 and Leu568 numbered
\end{abstract}

Electronic supplementary material The online version of this article (doi:10.1007/s00775-011-0812-9) contains supplementary material, which is available to authorized users.

S. Dell'Acqua · I. Moura · J. J. G. Moura (凹) ·

S. R. Pauleta $(\bowtie)$

REQUIMTE/CQFB,

Departamento de Química,

Faculdade de Ciências e Tecnologia,

Universidade Nova de Lisboa,

2829-516 Caparica, Portugal

e-mail: jose.moura@dq.fct.unl.pt

S. R. Pauleta

e-mail: srp@dq.fct.unl.pt according to the $P$. nautica $\mathrm{N}_{2} \mathrm{OR}$ sequence). Moreover, we built a model for Wolinella succinogenes $\mathrm{N}_{2} \mathrm{OR}$, an enzyme that has an additional $c$-type-heme-containing domain. The structures of the $\mathrm{N}_{2} \mathrm{OR}$ domain and the $c$-type-heme-containing domain were modeled and the full-length structure was obtained by molecular docking simulation of these two domains. The orientation of the $c$-type-heme-containing domain relative to the $\mathrm{N}_{2} \mathrm{OR}$ domain is similar to that found in the other electron transfer complexes.

Keywords Electron transfer complexes - Docking · Recognition - Nitrous oxide reductase $\cdot$ Electron transfer pathway

\section{Introduction}

Electron transfer reactions between proteins are essential for a large number of biological processes that include redox changes, such as some metabolic processes, photosynthesis, and both aerobic and anaerobic respiration. In most bacteria, the denitrification pathway is induced by low oxygen tensions or anaerobic conditions in the presence of nitrate and involves the reduction of nitrate to nitrogen $\left(\mathrm{N}_{2}\right)$ $[1,2]$. This global conversion is catalyzed by a group of enzymes, nitrate reductases, nitrite reductases, nitric oxide reductases, and nitrous oxide reductases $\left(\mathrm{N}_{2} \mathrm{ORs}\right)$, that contain transition metals as cofactors. The global process requires ten electrons that must be transferred stepwise to these enzymes through small electron donor proteins, such as $c$-type cytochromes or type 1 copper proteins, such as pseudoazurins and azurins [1,2].

In general, electron transfer complexes are part of a group of protein-protein complexes, the transient complexes, that are characterized by a short lifetime (on the 
millisecond timescale) and a low binding affinity $\left(K_{\mathrm{d}}\right.$ in the millimolar to micromolar range) [3, 4]. This transient nature distinguishes the electron transfer complexes from the more stable, long-lived protein-protein complexes, such as inhibitor-enzyme complexes, antigen-antibody complexes, and signal transduction complexes.

The transient nature of these complexes, necessary for a rapid electron transfer, makes them difficult to crystallize. As a consequence, only a few three-dimensional structures of complexes of this type have been determined by X-ray crystallography [5]. An alternative to the co-crystallization is offered by protein-protein docking simulations using the coordinates of the individual proteins, coupled with experimental data that provide information on the binding interface, such as mutagenesis studies and NMR chemical shift mapping.

Several docking algorithms have been developed [Attract, BiGGER, ClusPro, 3D-DOCK, DOT, Gramm-X, HADDOCK, ICM-DISCO, Molfit, PatchDock, RosettaDock, SKE-DOCK, Smooth-Dock, ZDOCK [6, and references therein], with HADDOCK and BiGGER being the ones mostly used to predict electron transfer complexes. In this study, we used bimolecular complex generation with global evaluation and ranking (BiGGER), which is included in the Chemera free software package [7].

BiGGER has been used in the last decade to obtain structural models of several electron transfer and proteinprotein complexes [8-10], in most cases when the threedimensional structures of the proteins involved are available and the residues at the interface are either not known or known only for one of the partners. Although the coordinates used are considered as "rigid bodies", the algorithm offers an option called "soft-docking" that takes into account the conformational freedom of some of the surface residue side chains, such as lysine, to assist the prediction of the mode of binding of the two proteins. However, for a complete analysis, the model structure of the complexes obtained needs to be validated by experimental data, such as from mutagenesis studies, kinetic studies of the electron transfer, or the identification of the interaction surface by chemical shift perturbation (using 2D NMR titrations).

In this work, the $\mathrm{N}_{2} \mathrm{OR}$ from different species, which catalyzes the final step of the bacterial denitrification pathway, the two-electron reduction of nitrous oxide $\left(\mathrm{N}_{2} \mathrm{O}\right)$ to dinitrogen $\left(\mathrm{N}_{2}\right)[2,11]$, is used as a case study. The three-dimensional structures of $\mathrm{N}_{2} \mathrm{OR}$ from Pseudomonas nautica [12], Paracoccus denitrificans [13], and Achromobacter cycloclastes [14] were solved recently, revealing the presence of two multicopper centers: a binuclear electron transfer center, $\mathrm{CuA}$ center, and a tetranuclear catalytic center, $\mathrm{CuZ}$ center. The large distance between the $\mathrm{CuA}$ and $\mathrm{CuZ}$ centers within the same monomer imposes the dimeric conformation of the enzyme, which is thus a functional homodimer, in which the two subunits are oriented "head to tail", bringing the $\mathrm{CuA}$ and $\mathrm{CuZ}$ centers to approximately $10 \AA$ from each other, a distance appropriate for an efficient electron transfer [15].

The binuclear $\mathrm{CuA}$ center of $\mathrm{N}_{2} \mathrm{OR}$ is located in a cupredoxin-like domain similar to that found in cytochrome $c$ oxidase and which in both cases constitutes the proposed docking and electron entry site from the small electron donor and enables transfer to the catalytic center $[11,16,17]$. The CuZ center is located in the N-terminal domain, which adopts a seven-blade $\beta$-propeller fold.

Recently, the physiological electron donor of $P$. nautica $\mathrm{N}_{2} \mathrm{OR}$ was identified to be cytochrome $c$-552 [18]. A steady-state kinetic study demonstrated that the interaction between the two proteins is mainly hydrophobic in nature and that mitochondrial cytochrome $c$ is not a competent electron donor to this enzyme [18]. On the other hand, $\mathrm{N}_{2} \mathrm{OR}$ isolated from Paracoccus pantotrophus, an organism closely related to $P$. denitrificans, can accept electrons from cytochrome $c-550$ and pseudoazurin [19-21], and also from the mitochondrial cytochrome $c$ [22]. A structural model for the electron transfer complex between $P$. denitrificans $\mathrm{N}_{2} \mathrm{OR}$ and either $P$. panthotropus cytochrome $c-550$ or $P$. panthotropus pseudoazurin has been proposed on the basis of a theoretical docking study [23]. In the case of $A$. cycloclastes $\mathrm{N}_{2} \mathrm{OR}$, its electron donor was shown to be only pseudoazurin [24], since no small cytochrome $c$ was identified in the periplasm of the bacteria growing under denitrifying conditions [25]. Nevertheless, it was shown that bovine heart cytochrome $c$ was also able to reduce the CuA center [26].

In Wolinella succinogenes, a host-associated organism from the Epsilonproteobacteria group, an $\mathrm{N}_{2} \mathrm{OR}$ was identified and isolated that exhibits a unique structural feature with an additional $\mathrm{C}$-terminal domain containing a $c$-type heme, which is not present in any other $\mathrm{N}_{2} \mathrm{OR}$ that has been isolated [27]. This $\mathrm{N}_{2} \mathrm{OR}$ receives electrons from a small periplasmic $c$-type cytochrome isolated from the same organism [28].

The purpose of this study was to analyze the electron transfer complexes formed between $P$. nautica $\mathrm{N}_{2} \mathrm{OR}$, $P$. denitrificans $\mathrm{N}_{2} \mathrm{OR}$, and $A$. cycloclastes $\mathrm{N}_{2} \mathrm{OR}$ and their physiological electron donors using a molecular docking approach, and to compare the results obtained with those for the nonphysiological redox partners. The ab initio calculated docked solutions were filtered using the properties of the electron transfer complexes derived from the kinetic studies. The putative model structures are discussed in terms of selectivity of binding and the electron transfer pathway. Moreover, a model for $W$. succinogenes $\mathrm{N}_{2} \mathrm{OR}$ was built and this structure was compared with the model structure of an electron transfer complex of a small $c$-type cytochrome docked to $\mathrm{N}_{2} \mathrm{OR}$. 


\section{Methods}

Molecular docking simulation

Molecular docking simulations were performed using the algorithm BiGGER developed by Palma et al. [7]. The target protein was the functional dimer of $\mathrm{N}_{2} \mathrm{OR}$ and the probes were each putative electron donor proteins. The coordinates for the P. nautica $\mathrm{N}_{2} \mathrm{OR}$ (1QNI [12]), $P$. denitrificans $\mathrm{N}_{2} \mathrm{OR}$ (1FWX [13]), A. cycloclastes $\mathrm{N}_{2} \mathrm{OR}$ (2IWF [14]), P. nautica cytochrome $c$-552 (1CNO [29]), $P$. denitrificans cytochrome $c$-550 (1COT [30]), P. panthotropus pseudoazurin (3ERX [31]), A. cycloclastes pseudoazurin (1BQR (reduced) [32]), horse heart cytochrome $c$ (1HRC [33]), and bovine heart cytochrome $c$ (2B4Z [34]) were obtained from the RCSB Protein Data Bank (http://www.rcsb.org).

The BiGGER algorithm provides a complete and systematic search of the rotational space of one protein relative to the other, generating a large number of putative docking geometries based on the complementarity of the molecular surfaces. The 5,000 best generated solutions were evaluated and ranked according to a combination of additional interaction criteria that included electrostatic energy of interaction, relative solvation energy, and the relative propensity of side chains to interact. For each solution, this evaluation process produces a "global score". The solutions can also be ranked according to each individual criterion, such as the electrostatic score or the hydrophobic score. The top solutions were analyzed using PISA (http://www.ebi.ac.uk/msd-srv/prot_int/pistart.html) to determine the size of the interface area of the complex and its hydrophobicity.

Analysis of the electrostatic surface potential

The electrostatic potential of the small electron donor proteins used in this study was generated in Chimera using the Coulombic law and partial charges from the Amber 99SB force field for all residues except for hemes, where the charges were calculated by the Gasteiger method [35]. The electrostatic potential of $\mathrm{N}_{2} \mathrm{ORs}$ used in this study was generated using the PDB2PQR server and the Adaptative Poisson-Boltzmann Solver plug-in in PyMOL (http://www. pymol.org).

Analysis of the electron transfer pathways

The donor-acceptor coupling constant and the most probable electron transfer pathway were predicted using the PATHWAYS algorithm [36, 37], which is included in the HARLEM molecular modeling program (http://www. kurnikov.org/harlem_manual/html/index.html). The electronic coupling matrix element $\left(H_{\mathrm{AB}}\right)$ depends strongly on the distance between the donor and the acceptor, since covalent bonds, and also hydrogen bonds to a lesser extent, produce a much stronger electronic coupling than a through-space connection [38].

Sequence analysis and alignment

Sequence alignment was carried out using the program ClustalW [39] on the EBI Web site. The WHISCY program [40] was used to predict the $\mathrm{N}_{2} \mathrm{OR}$ residues involved in protein-protein interfaces. This program is based on sequence conservation and also takes into account structural information.

Model building for W. succinogenes $\mathrm{N}_{2} \mathrm{OR}$

The model of the N-terminal domain of $W$. succinogenes $\mathrm{N}_{2} \mathrm{OR}$ was obtained through the Web-based Protein Homology/analogY Recognition Engine [41] (PHYRE; http://www.sbg.bio.ic.ac.uk/phyre/), whereas the C-terminal domain was modeled using both PHYRE and SWISSMODEL [42]. Putative model structures of W. succinogenes $\mathrm{N}_{2} \mathrm{OR}$ were predicted by analysis of the complexes obtained from the docking, performed with the BiGGER algorithm [7], between the model structure of the $\mathrm{N}_{2} \mathrm{OR}$ domain and $c$-type-heme-containing domain.

\section{Results and discussion}

Surface homology analysis of partner proteins

$\mathrm{N}_{2} \mathrm{OR}$ is a homodimer, with each monomer being composed of two domains. The $\mathrm{N}$-terminal domain has a sevenblade $\beta$-propeller fold, which is named the catalytic domain, since it holds the $\mathrm{CuZ}$ center, whereas the C-terminal domain, containing the $\mathrm{CuA}$ center, has a cupredoxin fold and is the electron transferring domain. In Fig. 1a, c, and e, the structures of the three $\mathrm{N}_{2} \mathrm{OR}$ used in this study (from P. nautica, $P$. denitrificans, and A. cycloclastes) are represented as backbones, evidencing their functional homodimeric structure, whereas in Fig. 1b, d, and $\mathrm{f}$ their surfaces are shown colored by electrostatic potential.

The comparison of the electrostatic surface of these $\mathrm{N}_{2} \mathrm{ORs}$ reveals that the region around the $\mathrm{CuA}$ center, which is the proposed electron entry point, has a negative patch, which differs in size depending on the enzyme. In the case of $P$. nautica $\mathrm{N}_{2} \mathrm{OR}$, the electrostatic surface is the least negative, whereas $P$. denitrificans $\mathrm{N}_{2} \mathrm{OR}$ has the most negative surface. Although the net charge of $P$. nautica $\mathrm{N}_{2} \mathrm{OR}$ dimer, -38 , is similar to that of $A$. cycloclastes $\mathrm{N}_{2} \mathrm{OR}$ dimer, -44 , their electrostatic surfaces around the 

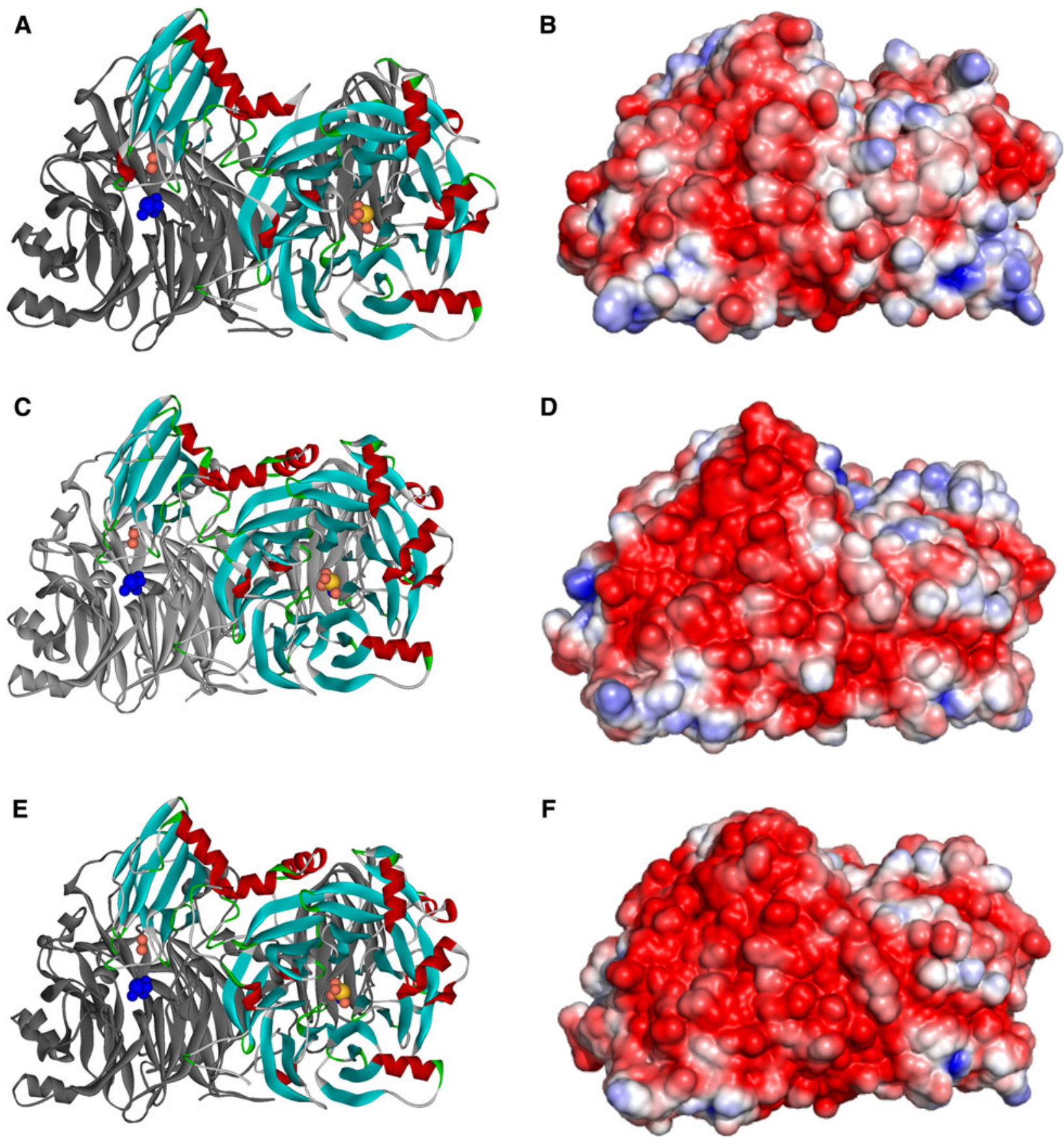

Fig. 1 Structures and electrostatic surface potentials of Pseudomonas nautica nitrous oxide reductase $\left(\mathrm{N}_{2} \mathrm{OR}\right)$ (a, b), Achromobacter cycloclastes $\mathrm{N}_{2} \mathrm{OR}$ (c, d), and Paracoccus denitrificans $\mathrm{N}_{2} \mathrm{OR}$ $(\mathbf{e}, \mathbf{f}) . \mathbf{a}, \mathbf{c}, \mathbf{e}$ The $\mathrm{CuA}$ and $\mathrm{CuZ}$ centers of the same monomer are colored blue and light pink, respectively. One of the $\mathrm{N}_{2} \mathrm{OR}$ monomers

CuA center are quite different, with A. cycloclastes $\mathrm{N}_{2} \mathrm{OR}$ being more negative and with a negative patch more similar to that of $P$. denitrificans $\mathrm{N}_{2} \mathrm{OR}$ dimer (which has a global charge of -62).

As already suggested in previous studies [23, 43], the sequence alignment shows a high homology between

is colored by secondary structure and the other is gray. The electrostatic surface potential is represented between -3 and $3 k T / e$ (b, d, f) (see "Methods"). The images were prepared using WebLab Viewer (Accelrys) (a, c, e) and PyMOL (b, d, f)

A. cycloclastes $\mathrm{N}_{2} \mathrm{OR}$ and $P$. denitrificans $\mathrm{N}_{2} \mathrm{OR}$, consisting of $89 \%$ identity, whereas $P$. nautica $\mathrm{N}_{2} \mathrm{OR}$ has a lower sequence identity relative to the other two enzymes, with $59 \%$ identity with $P$. denitrificans $\mathrm{N}_{2} \mathrm{OR}$ and $60 \%$ identity with $A$. cycloclastes $\mathrm{N}_{2} \mathrm{OR}$ (Fig. S1). Moreover, the mapping of these conserved residues onto the structure of 

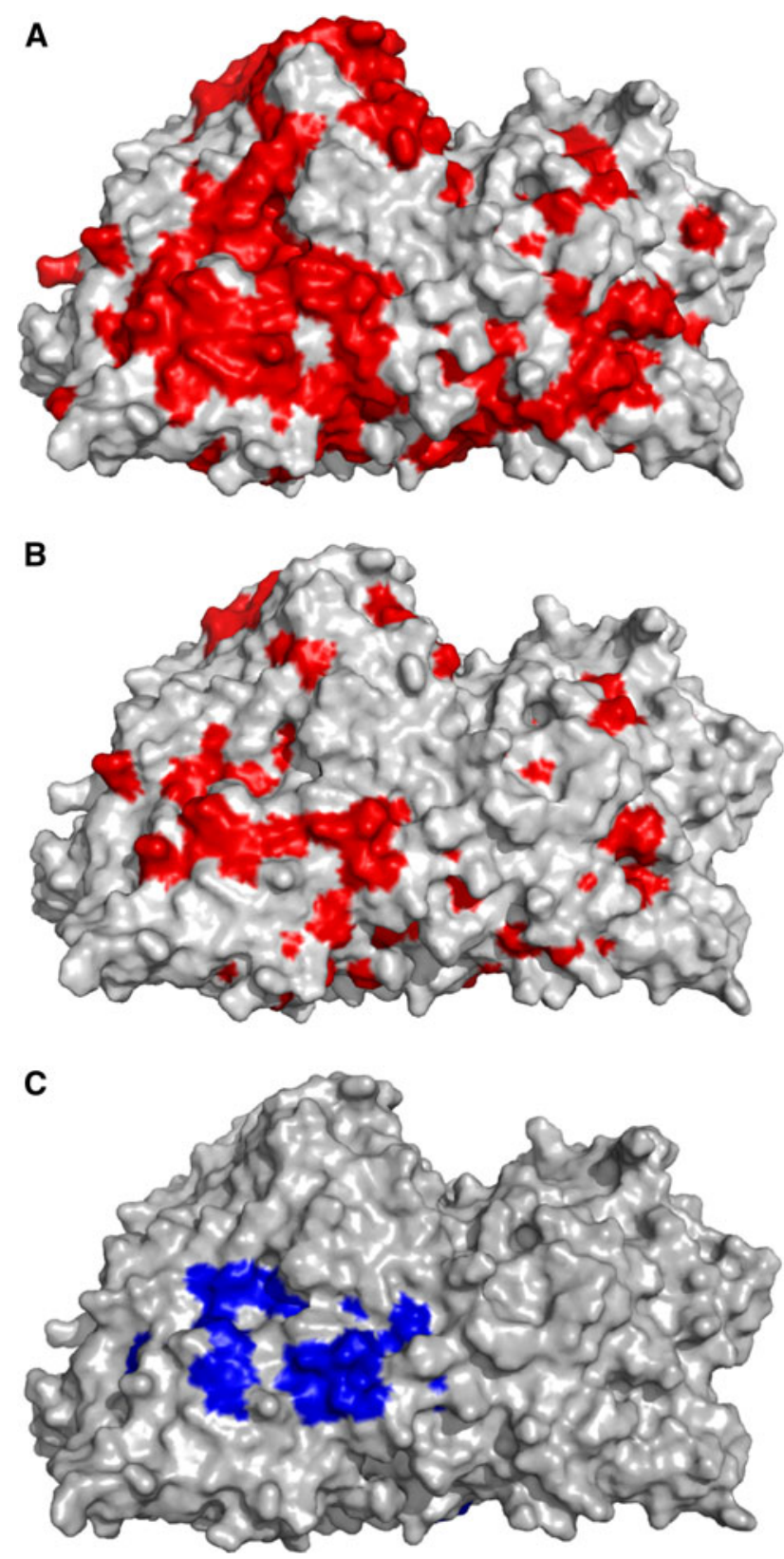

Fig. 2 a The conserved residues of $P$. nautica, $P$. denitrificans, and A. cycloclastes $\mathrm{N}_{2} \mathrm{ORs}$ mapped onto the $P$. nautica $\mathrm{N}_{2} \mathrm{OR}$ surface are colored red. $\mathbf{b}$ The conserved residues of $P$. nautica, $P$. denitrificans, A. cycloclastes, and Wolinella succinogenes $\mathrm{N}_{2} \mathrm{ORs}$ mapped onto the $P$. nautica $\mathrm{N}_{2} \mathrm{OR}$ surface are colored red. c Putative residues involved in the protein-protein interaction identified by WHISCY mapped onto the $P$. nautica $\mathrm{N}_{2} \mathrm{OR}$ surface are colored blue. The images were prepared using WebLab Viewer (Accelrys)

$P$. nautica $\mathrm{N}_{2} \mathrm{OR}$ identifies highly conserved regions, which include the interface between the two subunits, the residues coordinating the $\mathrm{CuA}$ and $\mathrm{CuZ}$ centers, and the surface near the CuA domain (Fig. 2a) [13].

The small electron carrier proteins that were used in the docking simulations are represented in Fig. 3. These proteins are either $c$-type cytochromes or type 1 copper proteins, and play the role of electron shuttles in the respiration and/or denitrification pathways.

Similarly to the analysis presented before for the $\mathrm{N}_{2} \mathrm{ORs}$ used in this study, the global charges and the electrostatic surfaces of the small proteins were compared. Their global charges are quite different, ranging from positive, for mitochondrial cytochrome $c(+8)$ and $P$. nautica cytochrome $c-552(+3)$, to neutral in the case of $A$. cycloclastes pseudoazurin and negative for $P$. denitrificans cytochrome $c-550(-2)$ and $P$. panthotropus pseudoazurin (-5).

However, even though they differ in their global charge, they share some common features. Indeed, all these small electron carrier proteins have a ring of positive residues around the proposed electron entry/exit point, which is located in a region composed mainly of hydrophobic residues (Fig. 3). The only exception is $P$. nautica cytochrome $c$-552, in which the number of charged residues around the exposed heme edge is clearly lower than in the other proteins (Fig. 3a). This cytochrome also differs from the other small proteins by being a homodimer, whereas the others are monomers (mitochondrial cytochrome $c$ and A. cycloclastes pseudoazurin) or there is a monomer-dimer equilibrium dependent on the redox state $(P$. denitrificans and $P$. panthotropus cytochrome $c-550$ and pseudoazurin) [44].

In general, electrostatic interactions are proposed to be instrumental in the preorientation of the partners for the formation of the encounter complex and less important in the interface of the competent electron transfer complex. The presence of a large number of opposite charges in the interface of the complex can be detrimental for an efficient electron transfer, as one of the requirements to maintain the electron flow in a pathway is fast dissociation of the partners after electron transfer [4]. Indeed, it has been proposed that the reason for the presence, in the electron carriers, of salt bridges between the residues that compose the positive ring and nearby negatively charged residues is to attenuate the formation of strong electrostatic interactions at the interface of the electron transfer complex [44].

In the surface of the donor protein, besides this region of charged residues, there is a hydrophobic patch that surrounds the exposed entry/exit site of the electron [45]. This hydrophobic patch includes the exposed heme edge in the case of $c$-type cytochromes or an exposed histidine side chain that coordinates the copper center in the case of pseudoazurins [46, 47] (Fig. 3).

Another characteristic of the small electron transfer proteins is their "pseudo-specificity", which is the property that allows these small electron transfer proteins to function as electron donors to different enzymes in an electron transfer pathway, as the denitrification or aerobic electron transfer chain. In the case of pseudoazurin and cytochrome 

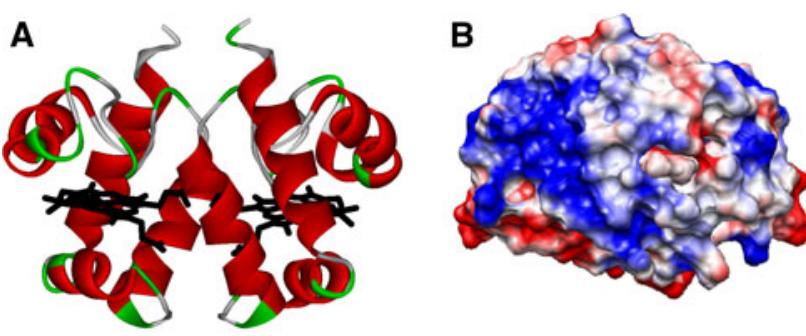

C

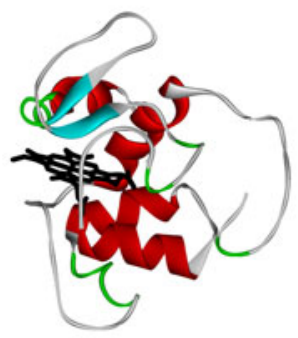

E

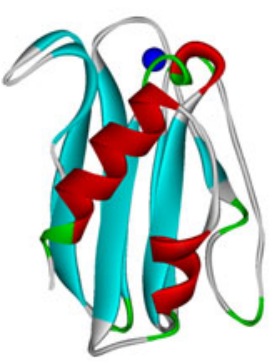

G

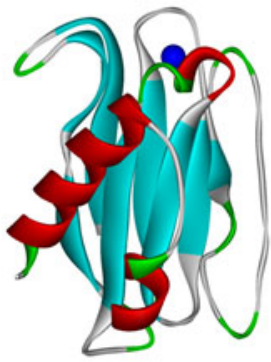

I
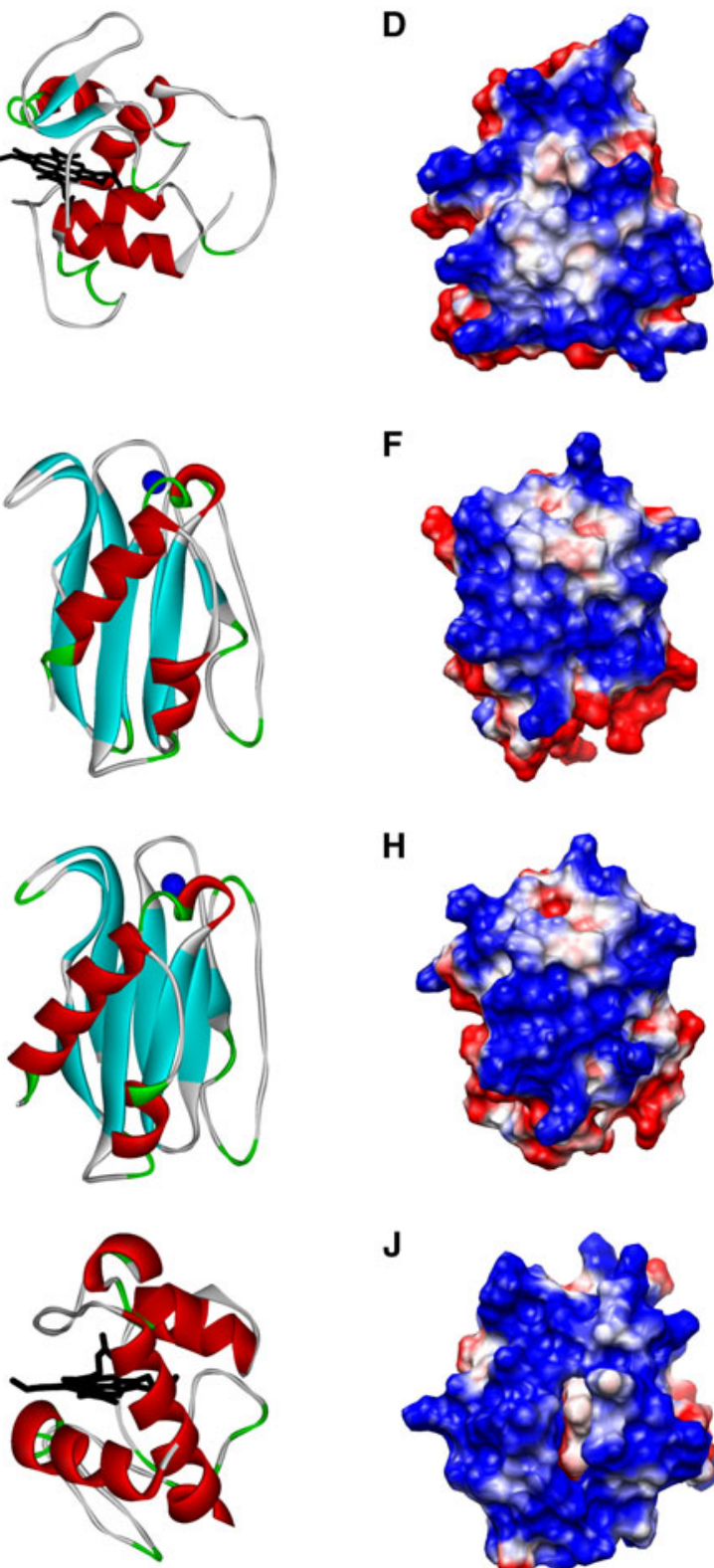

4 Fig. 3 Structures and electrostatic surface potentials of $P$. nautica cytochrome $c$-552 (a, b), P. denitrificans cytochrome $c-550(\mathbf{c}, \mathbf{d})$, Paracoccus panthotropus pseudoazurin (e, f), A. cycloclastes pseudoazurin $(\mathbf{g}, \mathbf{h})$, and horse heart cytochrome $c(\mathbf{i}, \mathbf{j})$. a, c, e, g, i The backbone is colored according to secondary structure and the heme group is colored black, whereas the copper atom is blue. The electrostatic surface potential is represented between -4 and $4 k T / e$ (see "Methods"). The images on the right are rotated by $90^{\circ}$ with respect to those on the left, so the proposed electron entry site is facing the reader. The images were prepared using the USCF Chimera program [35]

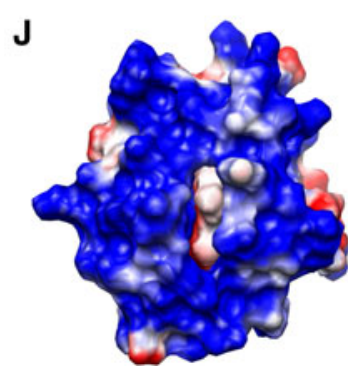

c-550 from P. panthotropus, it has been shown that they can both donate electrons to enzymes expressed in the periplasm of this organism when the bacterium is grown under microaerophilic or anaerobic conditions [48, 49].

In this study, it was also possible to assess the interspecies pseudo-specificity by determining whether some of the small electron carriers could potentially substitute the physiological donor of $\mathrm{N}_{2} \mathrm{OR}$ in in vitro kinetic assays.

The comparison of the electrostatic surface of the small electron transfer proteins and of the enzymes from the different organisms shows that there are pairs of proteins that could be putative electron donors, whereas there are others that would be more difficult to conceive as redox partners. One of these examples is the interaction of mitochondrial cytochrome $c$ and $P$. nautica $\mathrm{N}_{2} \mathrm{OR}$, which is actually not kinetically competent [18].

Molecular docking simulation

\section{General analysis}

A docking analysis of the complex formed between A. cycloclastes $\mathrm{N}_{2} \mathrm{OR}, P$. denitrificans $\mathrm{N}_{2} \mathrm{OR}$, and $P$. nautica $\mathrm{N}_{2} \mathrm{OR}$ and the corresponding physiological or a group of nonphysiological electron donors was performed. In each case, the first stage of the BiGGER algorithm provided a set of 5,000 solutions chosen from all the possible orientations generated by rotating the small electron donor (probe) around the surface of each $\mathrm{N}_{2} \mathrm{OR}$ (target) in steps of $1 \AA$ and with a translation step of $15^{\circ}$. In the second stage, the top solutions ranked by global score and either hydrophobic score or electrostatic score, depending on the nature of the electron transfer complex (see "Methods" and vide infra), were analyzed taking into account the distance between the redox centers.

Although the primary sequence of $P$. panthotropus $\mathrm{N}_{2} \mathrm{OR}$ is not known, it is expected to have a high identity with the $P$. denitrificans enzyme considering the high sequence identity that is found in other proteins from these two organisms (92 and 95\% sequence identity for cytochrome $c-550$ and pseudoazurin, respectively). This high homology justifies not only the use of the $P$. panthotropus pseudoazurin structure in the docking studies, but also the use of the biochemical properties of $P$. panthotropus $\mathrm{N}_{2} \mathrm{OR}$. It was reported that the increase in ionic strength decreases the activity of $P$. panthotropus $\mathrm{N}_{2} \mathrm{OR}$ in the presence of horse heart cytochrome $c$, which is an indication that the complex formed has an electrostatic nature [22]. The 
electrostatic character has also been suggested for other electron transfer complexes involving pseudoazurin and/or cytochrome $c-550$ from these organisms, and $P$. panthotropus cytochrome $c$ peroxidase [48] and P. denitrificans non-heme-iron hydroxylamine oxidase [50].

In the case of P. nautica $\mathrm{N}_{2} \mathrm{OR}$, the complex formed with cytochrome $c-552$, the physiological electron donor, is hydrophobic [18]. Although there is no report in the literature about the nature of the interaction of A. cycloclastes $\mathrm{N}_{2} \mathrm{OR}$ with its electron donor, pseudoazurin, there are several studies that have shown that the A. cycloclastes copper-containing nitrite reductase and A. cycloclastes pseudoazurin form an electrostatic complex [51, 52]. Thus, we propose that the electron transfer complex between A. cycloclastes pseudoazurin and A. cycloclastes $\mathrm{N}_{2} \mathrm{OR}$ has a similar nature.

Therefore, in the second stage of the docking, the putative complexes were analyzed taking into account the properties of these complexes as presenting an electrostatic or a hydrophobic character: the top 200 solutions were ranked by global, electrostatic, or hydrophobic score (their representations are shown in Figs. 4, S2-S4).

Previously, direct electron transfer studies have shown for $P$. panthotropus and $P$. nautica $\mathrm{N}_{2} \mathrm{OR}$ that the small electron transfer proteins donate electrons directly to the binuclear $\mathrm{CuA}$ center of $\mathrm{N}_{2} \mathrm{OR}[18,22]$. Therefore, the solutions were filtered using the condition that the distance between the redox centers, the $\mathrm{CuA}$ center and the iron ion of cytochrome $c$, or the copper ion of pseudoazurin, should be less than $20 \AA$, a condition required for an efficient electron transfer [15] (Table 1, and their representation is shown in Figs. S2-S4). This analysis is used to determine whether this docking program can be applied to discriminate between effective and noneffective electron donors.

In the case of $P$. nautica $\mathrm{N}_{2} \mathrm{OR}$, the complex with the electron donor cytochrome $c$-552 shows a higher number of putative effective electron transfer complexes for $\mathrm{N}_{2} \mathrm{OR}$ compared with any of the other nonphysiological electron carrier proteins (Figs. 4, S4; Table 1). The number of solutions with an appropriate distance between the redox
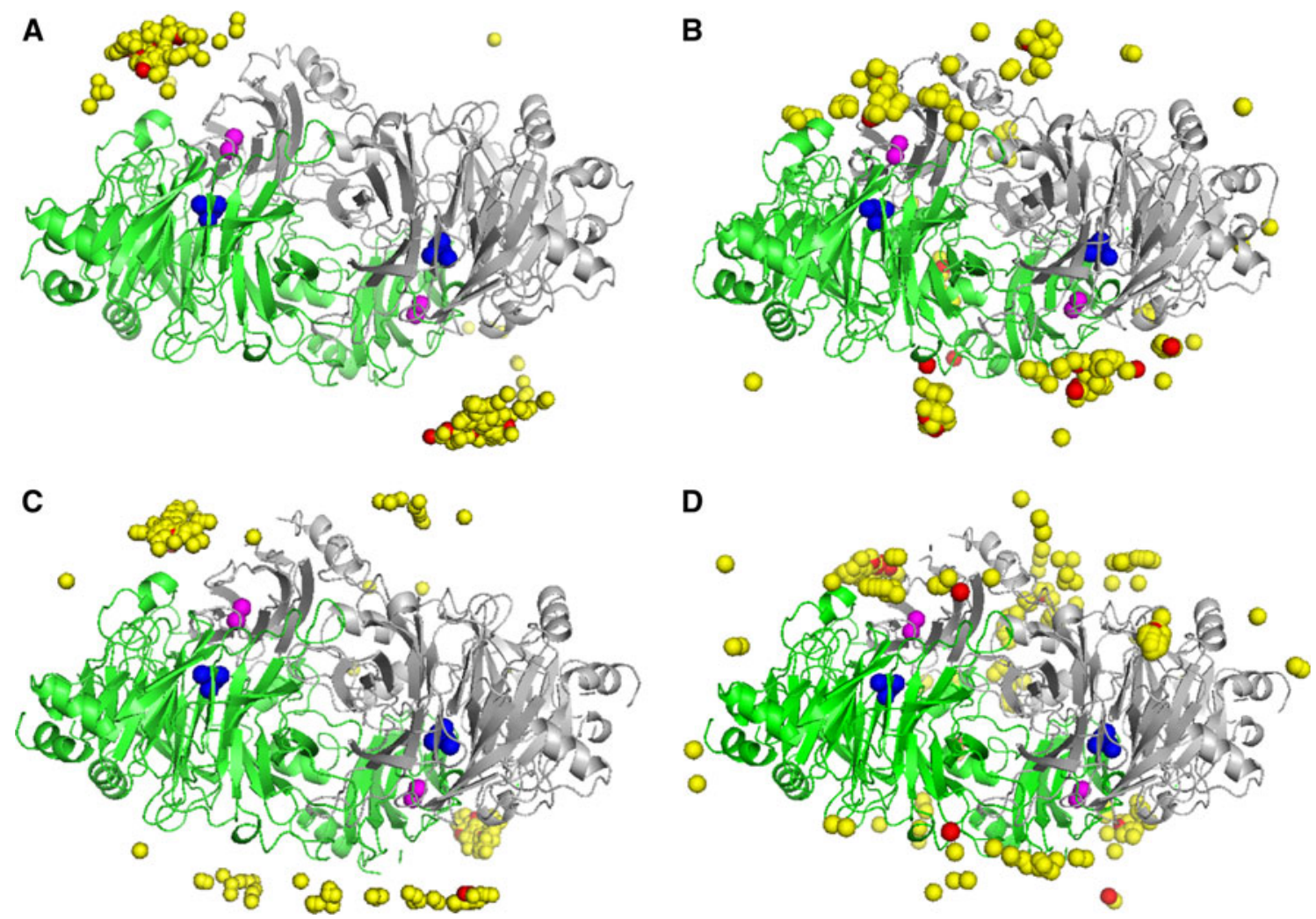

Fig. 4 The electron transfer complexes between $\mathrm{N}_{2} \mathrm{OR}$ and its physiological electron donors. a The 200 top docking solutions ranked by hydrophobic score of $P$. nautica $\mathrm{N}_{2} \mathrm{OR}$ with $P$. nautica cytochrome $c$-552. b The 200 top docking solutions ranked by electrostatic score of $A$. cycloclastes $\mathrm{N}_{2} \mathrm{OR}$ with A. cycloclastes pseudoazurin. c The 200 top docking solutions ranked by electrostatic score of $P$. denitrificans $\mathrm{N}_{2} \mathrm{OR}$ with $P$. denitrificans cytochrome $c$ 550. d The 200 top docking solutions ranked by electrostatic score of

P. denitrificans $\mathrm{N}_{2} \mathrm{OR}$ with $P$. panthotropus pseudoazurin. The geometric center for cytochrome $c$-552, the copper atom for pseudoazurin, and the iron atom for cytochrome $c-550$ are represented as yellow spheres, with the top 20 solutions of these scores being represented as red spheres. $\mathrm{N}_{2} \mathrm{OR}$ is shown as a backbone with one monomer colored green and the other colored gray, the two copper atoms of the $\mathrm{CuA}$ center are colored magenta, and the catalytic $\mathrm{CuZ}$ center is colored blue. The images were prepared using Chemera 
Table 1 Analysis of the molecular dockings between nitrous oxide reductase $\left(\mathrm{N}_{2} \mathrm{OR}\right)$ from different microorganisms and the electron donors performed using the BiGGER algorithm [7]

\begin{tabular}{|c|c|c|c|c|}
\hline $\mathrm{N}_{2} \mathrm{OR}$ source & Electron donor & $\begin{array}{l}\text { Best } 200 \mathrm{~Gb} \\
+d<20 \AA^{\mathrm{a}}\end{array}$ & $\begin{array}{l}\text { Best } 200 \text { electrostatic } \\
+d<20 \AA^{\mathrm{b}}\end{array}$ & $\begin{array}{l}\text { Best } 200 \text { hydrophobic } \\
+d<20 \AA^{\mathrm{c}}\end{array}$ \\
\hline Pseudomonas nautica & P. nautica cytochrome $c-552$ & 23 & 41 & 139 \\
\hline P. nautica & P. denitrificans cytochrome $c-550$ & 0 & 0 & 3 \\
\hline P. nautica & Paracoccus panthotropus pseudoazurin & 0 & 4 & 4 \\
\hline P. nautica & A. cycloclastes pseudoazurin & 1 & 4 & 8 \\
\hline P. nautica & Horse heart cytochrome $c$ & 0 & 0 & 0 \\
\hline Paracoccus denitrificans & P. nautica cytochrome $c-552$ & 4 & 34 & 66 \\
\hline P. denitrificans & P. denitrificans cytochrome $c-550$ & 9 & 83 & 80 \\
\hline P. denitrificans & P. panthotropus pseudoazurin & 5 & 20 & 35 \\
\hline P. denitrificans & A. cycloclastes pseudoazurin & 1 & 27 & 39 \\
\hline P. denitrificans & Horse heart cytochrome $c$ & 12 & 92 & 108 \\
\hline Achromobacter cycloclastes & P. nautica cytochrome $c-552$ & 8 & 79 & 62 \\
\hline A. cycloclastes & P. denitrificans cytochrome $c-550$ & 12 & 126 & 42 \\
\hline A. cycloclastes & P. panthotropus pseudoazurin & 9 & 26 & 40 \\
\hline A. cycloclastes & A. cycloclastes pseudoazurin & 6 & 85 & 55 \\
\hline A. cycloclastes & Horse heart cytochrome $c$ & 0 & 26 & 27 \\
\hline A. cycloclastes & Bovine heart cytochrome $c$ & 1 & 44 & 37 \\
\hline
\end{tabular}

The complexes that have been studied experimentally are highlighted in bold

${ }^{a}$ Number of solutions in the top 200 in the global score $(G b)$ ranking with a $\mathrm{CuA}-\mathrm{Fe} / \mathrm{Cu}$ distance shorter than $20 \AA$

b Number of solutions in the top 200 in the electrostatic ranking with a $\mathrm{CuA}-\mathrm{Fe} / \mathrm{Cu}$ distance shorter than $20 \AA$

c Number of solutions in the top 200 in the hydrophobic ranking with a $\mathrm{CuA}-\mathrm{Fe} / \mathrm{Cu}$ distance shorter than $20 \AA$

centers (heme-Fe and $\mathrm{CuA}$ ) is maximum considering the hydrophobic score, as predicted taking into account the kinetic studies [18]. Moreover, it was shown that the positively charged horse heart cytochrome $c$ was not able to donate electrons to $P$. nautica $\mathrm{N}_{2} \mathrm{OR}$, a result that corroborates the docking analysis, which does not present any solution with the appropriate orientation for electron transfer (Fig. S4.3).

On the other hand, this mitochondrial cytochrome was shown to be a competent electron donor to $P$. denitrificans $\mathrm{N}_{2} \mathrm{OR}$ [22], and indeed the analysis of the docking simulation by the different scores gives rise to several top solutions in an orientation that is predicted to enable an effective electron transfer (Table 1). The number of these top orientations for electron transfer is similar whatever scoring function was used to rank them, even if the formation of the competent electron transfer complexes is proposed to be mainly driven by electrostatic forces.

The physiological electron donors of $P$. denitrificans $\mathrm{N}_{2} \mathrm{OR}$ have long been established to be cytochrome $c-550$ and pseudoazurin [20, 21]. In the first case, the docking simulation gave several solutions in the top 200 of each ranking with a favorable orientation for electron transfer (Fig. 4c, d; Table 1). In the case of pseudoazurin, this protein has a lower number of probable solutions towards
P. denitrificans $\mathrm{N}_{2} \mathrm{OR}$ compared with cytochrome $c-550$ (vide infra).

Our results on $P$. denitrificans $\mathrm{N}_{2} \mathrm{OR}$ are widely in agreement with a previous docking analysis performed with a different algorithm, FTDOCK [23], which strengthens both the use of the docking algorithm BiGGER and the method employed in this work for the analysis of the 5,000 solutions obtained from the ab initio soft-docking calculation.

In the last case study, the molecular docking simulation between $A$. cycloclastes $\mathrm{N}_{2} \mathrm{OR}$ and its physiological electron donor, pseudoazurin, there are several putative docking solutions with a short distance between the redox center especially when the solution were ranked by the electrostatic score (Fig. 4b; Table 1).

The lower number of putative complexes obtained when pseudoazurins, from either A. cycloclastes or P. panthotropus, are used as probes can be attributed to the smaller size of the expected pseudoazurin surface interacting with $\mathrm{N}_{2} \mathrm{OR}$, when compared with that of the $c$-type cytochromes studied. Since there is a surface contact cutoff value below which BiGGER rejects all models, the number of "putatively competent" solutions that were rejected is expected to be higher in the docking calculations when pseudoazurin is a probe rather than in those in which cytochromes were used as probes. 
It is interesting to note that the mitochondrial bovine heart cytochrome $c$, which was shown to be able to donate electrons to the $\mathrm{CuA}$ center of A. cycloclastes $\mathrm{N}_{2} \mathrm{OR}$, indeed behaves as a potential electron donor, with a larger number of putative solutions being found when the complexes were analyzed considering the interaction driven mainly by electrostatic forces (Fig.S2.1). Similarly, $P$. denitrificans cytochrome $c-550$ was also predicted, by BiGGER, to function as a putative electron donor to this enzyme (considering that the interaction has an electrostatic nature). This can be explained by the fact that the surfaces of these two electron shuttle proteins share a similar charge distribution (Fig. 3).

A summary of the analysis of the docking simulations combined with the previous experimental data is presented in Table S1.

\section{Analysis of the top complexes}

The interface-accessible area of the top solutions for each of the physiologic docking results was evaluated. These complexes have an interface area between 943 and $1,368 \AA^{2}$ (Table 2), which is typical for small, short-lived complexes following the criteria of Lo Conte et al. [3]. The docking models for the $P$. nautica cytochrome $c$-552$P$. nautica $\mathrm{N}_{2} \mathrm{OR}$ complex have a higher percentage of apolar residues in the interface area (with an average value of $79 \%$ ), confirming the hydrophobic nature of the interaction. For A. cycloclastes $\mathrm{N}_{2} \mathrm{OR}$ and $P$. denitrificans $\mathrm{N}_{2} \mathrm{OR}$ complexes, the average values of apolar residues in the interface are 64 and $69 \%$, respectively. This result shows that although the formation of these complexes is being driven by electrostatic forces, the area of contact

Table 2 Parameters of the top model complex obtained by docking simulation of $\mathrm{N}_{2} \mathrm{OR}$ with the respective electron donor

\begin{tabular}{|c|c|c|c|c|c|c|c|c|c|}
\hline Complex & ID & $\mathrm{Gb}$ (rank) & Elect. (rank) & $\begin{array}{l}\text { Hydroph. } \\
\text { (rank) }\end{array}$ & $D^{\mathrm{a}}(\AA)$ & $\begin{array}{l}\text { Coupling } \\
\text { constant }^{\mathrm{b}}\end{array}$ & Pathway ${ }^{c}$ & $\begin{array}{l}\text { Interface } \\
\text { area }\left(\AA^{2}\right)\end{array}$ & $\begin{array}{l}\text { Apolar } \\
\text { residues }^{\mathrm{d}} \\
(\%)\end{array}$ \\
\hline $\begin{array}{l}\text { A. cycloclastes } \\
\mathrm{N}_{2} \mathrm{OR} \text {-bovine heart } \\
\text { cytochrome } c\end{array}$ & 4142 & 1.9 (387) & $-151.7(56)$ & $-6.0(440)$ & 15.7 & $2.8 \times 10^{-5}$ & Fe-Ala554 & 1,366 & 66 \\
\hline $\begin{array}{l}\text { A. cycloclastes } \\
\mathrm{N}_{2} \mathrm{OR}-A \text {. cycloclastes } \\
\text { pseudoazurin }\end{array}$ & 3203 & $2.2(102)$ & $-91.5(49)$ & $-5.4(918)$ & 16.9 & $1.1 \times 10^{-4}$ & $\mathrm{Cu}-\mathrm{Leu} 627$ & 1,090 & 63 \\
\hline $\begin{array}{l}\text { A. cycloclastes } \\
\mathrm{N}_{2} \mathrm{OR}-A \text {. cycloclastes } \\
\text { pseudoazurin }\end{array}$ & 3167 & $2.1(140)$ & $-78.4(162)$ & $-6.6(266)$ & 18.9 & $9.4 \times 10^{-6}$ & $\mathrm{Cu}-\mathrm{Leu} 627$ & 1,115 & 64 \\
\hline $\begin{array}{l}P . \text { denitrificans } \\
\mathrm{N}_{2} \mathrm{OR}-P \text {. panthotropus } \\
\text { pseudoazurin }\end{array}$ & 3077 & $2.3(71)$ & -22.7 (298) & $-6.9(150)$ & 15.7 & $1.3 \times 10^{-5}$ & $\mathrm{Cu}-\mathrm{Leu} 593$ & 1,277 & 68 \\
\hline $\begin{array}{l}P . \text { denitrificans } \\
\mathrm{N}_{2} \mathrm{OR}-P \text {. denitrificans } \\
\text { cytochrome } c-550\end{array}$ & 4851 & $2.2(62)$ & $-101.4(152)$ & $-5.5(1,385)$ & 14.7 & $4.7 \times 10^{-4}$ & $\mathrm{Cu}-\mathrm{His} 635$ & 1,368 & 67 \\
\hline $\begin{array}{l}\text { P. denitrificans } \\
\mathrm{N}_{2} \mathrm{OR} \text {-horse heart } \\
\text { cytochrome } c\end{array}$ & 1712 & $1.9(86)$ & $-175.1(121)$ & $-6.7(38)$ & 15.5 & $2.8 \times 10^{-4}$ & Fe-His635 & 1,289 & 70 \\
\hline $\begin{array}{l}P . \text { nautica } \\
\mathrm{N}_{2} \mathrm{OR}-P \text {. nautica } \\
\text { cytochrome } c-552\end{array}$ & 105 & $10.4(35)$ & $-22.7(3,545)$ & $-6.1(13)$ & 16.3 & $3.0 \times 10^{-5}$ & Fe-Asp519 & 1,222 & 75 \\
\hline $\begin{array}{l}\text { P. nautica } \mathrm{N}_{2} \mathrm{OR}- \\
\text { P. nautica cytochrome } \\
\text { c-552 }\end{array}$ & 579 & $9.2(51)$ & $-50.7(312)$ & $-7.0(2)$ & 17.5 & $3.0 \times 10^{-5}$ & $\mathrm{Fe}-\mathrm{Gln} 497$ & 1,211 & 79 \\
\hline $\begin{array}{l}\text { P. nautica } \mathrm{N}_{2} \mathrm{OR}- \\
\text { P. nautica cytochrome } \\
c-552\end{array}$ & 2181 & $10.4(36)$ & $-39.6(1,118)$ & $-4.8(175)$ & 17.9 & $2.1 \times 10^{-6}$ & Fe-His566 & 943 & 84 \\
\hline
\end{tabular}

$G b$ global score, Elect. electrostatic score, Hydroph. hydrophobic score, rank ranking of the solution with that ID in the respective score

${ }^{a}$ Distance between $\mathrm{CuA}$ in $\mathrm{N}_{2} \mathrm{OR}$ and heme-Fe or $\mathrm{Cu}$ of cytochrome $c$ or pseudoazurin, respectively

b The coupling constant is the value for the best electron transfer path from $\mathrm{Cu}$ or Fe atoms to $\mathrm{CuA}$ centers as analyzed using PATHWAYS

c The residue number is according to the primary sequence of $\mathrm{N}_{2} \mathrm{OR}$ from each organism

d The percentage of apolar residues in the interface area of the complex 
between the redox partners is hydrophobic, as expected in order to promote the electron transfer and provide more specificity to the complex [45].

The electron transfer complexes between $A$. cycloclastes $\mathrm{N}_{2} \mathrm{OR}$ and $P$. denitrificans $\mathrm{N}_{2} \mathrm{OR}$ and their electron donors can be ascribed to a docking scenario in which the electrostatic forces play the role of the long-range recognition between the donor and the acceptor and drive the formation of the complex; however, at short range, the hydrophobic patch also plays an important role in the fine-tuning of formation of the electron transfer complex.

\section{Electron transfer pathway}

To propose an electron pathway from the small electron donor protein to the $\mathrm{CuA}$ center and then to the catalytic center of $\mathrm{N}_{2} \mathrm{OR}$, the $\mathrm{CuZ}$ center, the top complexes for each of the docking calculations were further analyzed using the program PATHWAYS. The top complexes that were chosen had to obey the following criteria (Table 2):

- They had to be part of the top 200 solutions ranked by global score.

- They had to be part of the top solutions ranked by hydrophobic score for $P$. nautica $\mathrm{N}_{2} \mathrm{OR}$ or by electrostatic score for P. denitrificans $\mathrm{N}_{2} \mathrm{OR}$ and A. cycloclastes $\mathrm{N}_{2} \mathrm{OR}$ docked complexes.

- The distance between the redox center of the small electron donor and the CuA center of $\mathrm{N}_{2} \mathrm{OR}$ had be shorter than $20 \AA$.

Combining the analysis of the electron transfer pathway of the top complexes, we identified a conserved histidine (A. cycloclastes His625, P. denitrificans His635, and $P$. nautica His566) in the electron transfer pathway as the entry point in three of the complexes analyzed (Table 2), a leucine (A. cycloclastes Leu627, P. denitrificans Leu637, and $P$. nautica Leu568) in two complexes, and an aspartate (A. cycloclastes Asp578, P. denitrificans Asp588, and P. nautica Asp519), an alanine (A. cycloclastes Ala554, P. denitrificans Ala564, and P. nautica Ala495), a glutamine ( $P$. nautica Gln497, which corresponds to A. cycloclastes Ser556 and $P$. denitrificans Ser566), and a leucine (A. cycloclastes Leu583 and P. denitrificans Leu593, which corresponds to $P$. nautica Val524) each just in one identified electron pathway (Table 2).

The sequence alignment shows that all these residues are conserved in the primary sequence of these $\mathrm{N}_{2} \mathrm{ORs}$, suggesting that these residues constitute a conserved region located near the $\mathrm{CuA}$ center that functions both as the binding site for the electron donor and as the electron entry point (Figs. 2a, 5a).

This conserved patch involved in complex formation and favorable electron transfer was also identified by the
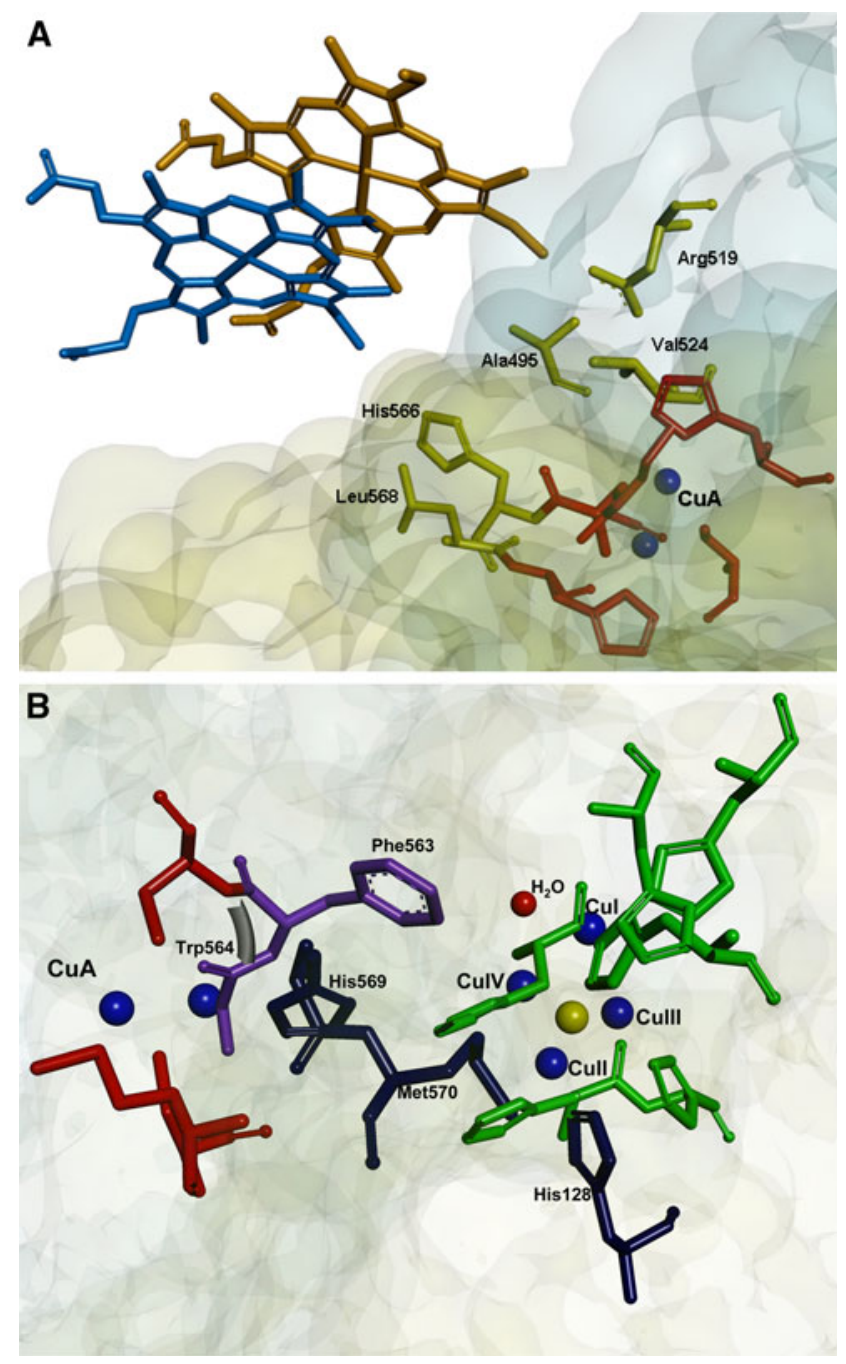

Fig. 5 Proposed electron transfer pathways in $\mathrm{N}_{2} \mathrm{OR}$. a The electron transfer pathway between cytochrome $c-552$ and the $\mathrm{CuA}$ center of $P$. nautica $\mathrm{N}_{2} \mathrm{OR}$ is represented. Two possible orientations of cytochrome $c-552$ are shown (for clarity only the heme group of cytochrome $c-552$ is displayed). The residues involved in the electron transfer from the heme group to the CuA center (Ala495, Asp519, Val524, His566, Leu568) are represented in yellow. The ligands of the CuA center (His526, Cys561, Cys565, His569, Met572) are colored red. The copper atoms of the $\mathrm{CuA}$ center are represented as blue spheres. b Two different electron transfer pathways from the $\mathrm{CuA}$ center to the $\mathrm{CuZ}$ center are represented. The first route involves Trp563, which is a CuA ligand, and the neighbor Phe564 (Trp563 and Phe564 are represented in purple); the electron is then transferred to the oxygen of a water molecule or a hydroxyl group bound between $\mathrm{CuI}$ and $\mathrm{CuIV}$ of the $\mathrm{CuZ}$ center. An alternative route involves the electron transfer from the CuA center to His569, then to Met570, and subsequently to His128, which is a ligand of $\mathrm{CuII}$ of the $\mathrm{CuZ}$ center (His569, Met570, and His128 are represented in blue). The ligands of the CuZ center (His79, His80, His128, His270, His325, His376, His437) are represented in green. The copper atoms of $\mathrm{CuZ}$ are represented as blue spheres, and the sulfur atom in the $\mathrm{CuZ}$ center is represented in yellow. In $\mathbf{a}$ and $\mathbf{b}$ the surfaces of the two monomers of $\mathrm{N}_{2} \mathrm{OR}$ are represented in light green and light blue, respectively 
WHISCY program [40] as to constitute a putative surface involved in protein-protein interaction (Fig. 2c-only the $P$. nautica $\mathrm{N}_{2} \mathrm{OR}$ surface is shown).

The coupling constants for this electron transfer pathway are between $4.7 \times 10^{-4}$ and $2.1 \times 10^{-6}$ (values calculated by PATHWAYS), in which the routes involving the surface conserved histidine (A. cycloclastes His625, $P$. denitrificans His635, and $P$. nautica His566) show the highest coupling constant $\left(4.7 \times 10^{-4}\right.$ and $2.8 \times 10^{-4}$ for P. denitrificans $\mathrm{N}_{2} \mathrm{OR}$ complexes, Table 2).

The electron transfer pathway from the $\mathrm{CuA}$ center to the $\mathrm{CuZ}$ center was also analyzed with the PATHWAYS program. The most probable electron transfer pathway (with a coupling constant of $1.1 \times 10^{-4}$ ) implies that the electron is transferred from the CuA center to the tryptophan (P. nautica Trp563, P. denitrificans Trp632, A. cycloclastes Trp622) that is bound to the copper through the main-chain carbonyl group. Then, the electron is transferred to the neighbor phenylalanine ( $P$. nautica Phe564, P. denitrificans Phe633, A. cycloclastes Phe623) and subsequently to the oxygen of a water molecule or a hydroxyl group, which is bound between two copper atoms of the $\mathrm{CuZ}$ center (CuI and CuIV) (Fig. 5bpathway represented in purple), the proposed substrate binding site [53].

Although the catalytic mechanism of $\mathrm{N}_{2} \mathrm{OR}$ is only partially known, theoretical calculations coupled with spectroscopic studies and enzymatic assays have shown that the most favorable state of the $\mathrm{CuZ}$ center to bind the substrate, $\mathrm{N}_{2} \mathrm{O}$, is the fully reduced state $\left(4 \mathrm{Cu}^{+}\right)$[54]. The electron transfer pathway identified above is in agreement with this mechanism, in which the reduction of the $\mathrm{CuZ}$ center occurs prior to substrate binding. After the first step of the reaction (the $\mathrm{N}-\mathrm{O}$ bond cleavage), the $\mathrm{CuZ}$ center is proposed to be in the $\left[2 \mathrm{Cu}^{2+}-2 \mathrm{Cu}^{+}\right]$redox state and has to undergo two one-electron reductions to be again in the catalytically active redox state $4 \mathrm{Cu}^{+}$[55]. During this reduction process, the oxygen bound to the $\mathrm{CuZ}$ center (between $\mathrm{CuI}$ and $\mathrm{CuIV}$ ) has to be protonated to be released as a water molecule.

An alternative electron pathway (with a coupling constant of $4.3 \times 10^{-5}$ ) involves one of the histidine ligands of the CuA center (P. nautica His569, P. denitrificans His638, A. cycloclastes His628), then the neighbor methionine (P. nautica Met570, P. denitrificans Met639, A. cycloclastes Met629), and then transfer of the electron to the histidine ( $P$. nautica His128, P. denitrifcans His194, A. cycloclastes His184), which is a ligand of one of the copper atoms of the CuZ center (CuII) (Fig. 5b-pathway represented in blue). This electron transfer route is analogous to that proposed for the electron transfer from the $\mathrm{CuA}$ center to the heme $a$ in cytochrome $c$ oxidase [56].
Model structure for $\mathrm{N}_{2} \mathrm{OR}$ from W. succinogenes

The $\mathrm{N}_{2} \mathrm{OR}$ from $W$. succinogenes has an additional domain in its $\mathrm{C}$-terminal with the canonical $c$-type-heme binding motif-CXXCH- [27, 28].

The structure of this protein has not yet been solved and can be proposed to resemble the electron transfer complex between an $\mathrm{N}_{2} \mathrm{OR}$ and a $c$-type cytochrome. A protein sequence homology search shows that there are a few organisms that have this type of $\mathrm{N}_{2} \mathrm{OR}$, although none of these other enzymes have been isolated. These organisms are from the Campylobacter, Sulfurimonas, and Denitrovibrio genera, with the first two being host-associated organisms from the Epsilonproteobacteria group, as W. succinogenes.

The model structure of $W$. succinogenes $\mathrm{N}_{2} \mathrm{OR}$ was built in two steps: first a model of the $\mathrm{N}$-terminal $\mathrm{N}_{2} \mathrm{OR}$ domain and of the $\mathrm{C}$-terminal $c$-type-heme-containing domain were modeled, and afterwards these two domains were docked to obtain a model structure of the complete enzyme.

The N-terminal $\mathrm{N}_{2} \mathrm{OR}$ domain, composed of the $\mathrm{CuA}$ and $\mathrm{CuZ}$ domains, shows sequence homology with all the $\mathrm{N}_{2} \mathrm{ORs}$ with known structure, and the surface mapping of the conserved residues shows that there is a surface patch of conserved residues near the CuA center (Fig. 2b), a region also identified by WHISCY as involved in proteinprotein interactions. However, since $P$. nautica $\mathrm{N}_{2} \mathrm{OR}$ has the highest primary sequence identity with $W$. succinogenes $\mathrm{N}_{2} \mathrm{OR}(34 \%)$, its structure (Protein Data Bank ID $1 \mathrm{QNI})$ was used to model the $\mathrm{N}$-terminal domain of W. succinogenes $\mathrm{N}_{2} \mathrm{OR}$ using the PHYRE program.

As to the C-terminal domain, proposed to contain a $c$-type heme, different online programs and $c$-type cytochromes or $c$-type-heme-containing domains were used to model its structure (Fig. 6a) on the basis of sequence homology. In particular, four models were created using the structures of the following $c$-type-heme-containing templates: Rhodothermus marinus $\mathrm{Caa}_{3}$ cytochrome $c$ domain (1W2L [57]), C-terminal domain of quinohemoprotein alcohol dehydrogenase from Pseudomonas putida HK5 (1KV9 [58]), the monohemic cytochrome $c_{2}$ from Rhodopila globiformis (1HRO [59]), and the monohemic cytochrome $c$ from $R$. marinus (3CP5 [60]). The latter has the highest sequence identity $(25 \%)$ and the model obtained gave the best results in the docking study. This model was obtained using SWISS-MODEL [42] (Fig. 6b), and shows that this domain has a surface with positive and negative patches (Fig. 6c, d), which is consistent with a solvent-exposed surface.

In the second stage, these two model structures, the $\mathrm{N}_{2} \mathrm{OR}$ domain and the $c$-type cytochrome domain, were used as the target and probe, respectively, in a docking calculation. It is important to mention that there is a region 
Fig. 6 The domains of $W$. succinogenes $\mathrm{N}_{2} \mathrm{OR}$ and of other $\mathrm{N}_{2} \mathrm{ORs}$ with known structure. The Protein Data Bank IDs of the structures used to model the $\mathrm{C}$-terminal domain are shown in $3 \mathrm{CP} 5$ were the ones that gave the highest scores for the $\mathrm{N}$-terminal domain and the and C-terminal domain, respectively. The N-terminal domain of $W$. succinogenes $\mathrm{N}_{2} \mathrm{OR}$ is composed of the $\mathrm{CuZ}$ domain (blue) and the $\mathrm{CuA}$ domain (purple), and the C-terminal domain containing the $c$-type-heme binding motif is represented as a red box. The model of the $\mathrm{C}$-terminal domain of W. succinogenes $\mathrm{N}_{2} \mathrm{OR}$ is shown as a backbone (b) and its surface is shown colored by electrostatic surface potential is represented between -4 and 4 $k T / e$ (calculated as described in "Methods" for the small $c$-type cytochromes). The images were prepared using the USCF Chimera program [35] red (a). Structures $1 \mathrm{QNI}$ and electrostatic potential $(\mathbf{c}, \mathbf{d})$. The

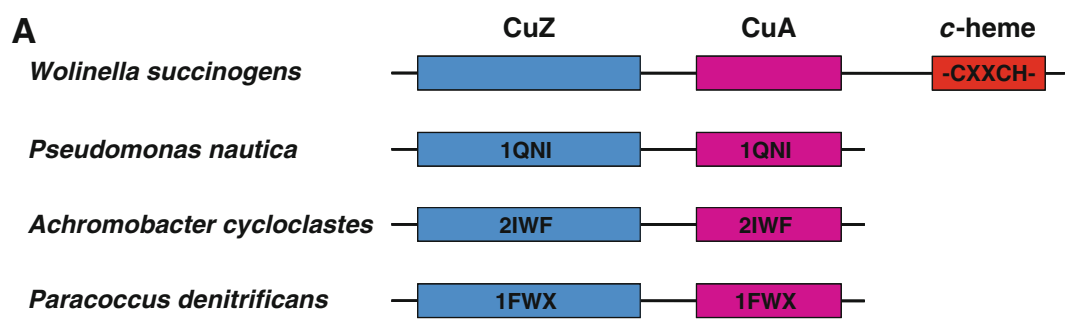

Rhodothermus marinus cyt. $c$

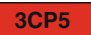

Rhodothermus marinus $\mathrm{caa}_{3}$ cyt. $c$ domain

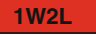

Pseudomonas putida alcohol dehydrogenase

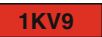

Rhodopila globiformis cyt. $c_{2}$
B

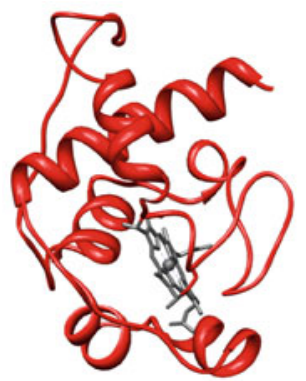

(100 residues) between the $\mathrm{N}$-terminal $\mathrm{N}_{2} \mathrm{OR}$-type domain and the C-terminal $c$-type-heme-containing domain which has very low homology with known protein structures. For this reason we cannot provide a realistic linker connecting the $\mathrm{N}$ - and the C-terminal domains. However, an acceptable docking geometry can be selected taking into account that for an effective electron transfer the distance between the $\mathrm{CuA}$ center and the heme iron of the heme in the C-terminal domain should be less than $20 \AA$.

The analysis of the docking results shows that there is one solution that fulfils this criterion, providing us with a possible model structure of $W$. succinogenes $\mathrm{N}_{2} \mathrm{OR}$ (Fig. 7a).

The PATHWAYS analysis of these two models determined a distance of 17.8 and $18.8 \AA$ between the heme iron and the $\mathrm{CuA}$ center, with Arg557 and Cys627 in the $\mathrm{N}_{2} \mathrm{OR}$ domain as the key residues for the electron entry. Arg557 corresponds to the conserved alanine proposed to be part of the electron transfer pathway in the other $\mathrm{N}_{2} \mathrm{OR}$ complexes studied (A. cycloclastes Ala554, P. denitrificans Ala564, and P. nautica Ala495), and Cys627 is the neighboring residue of Ser628, which corresponds to the conserved histidine residue proposed before to be the electron entry point (A. cycloclastes His625, P. denitrificans His635, and $P$. nautica His566).

The analysis of the electrostatic surface of the cytochrome $c$ domain modeled on the basis of $R$. marinus means that this domain might not be tightly bound to the $\mathrm{N}_{2} \mathrm{OR}$ domain. $c$-type-heme-containing domain can assume different orienpresent an "open conformation" to allow the $c$-type-hemecontaining domain to receive electrons from an electron donor domain, the enzyme can rearrange into a "close conformaentation to donate electrons to the CuA center (Fig. 7b).

\section{Conclusion} complexes [23].
C
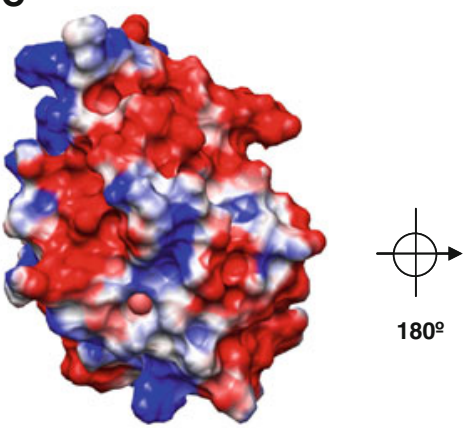

D

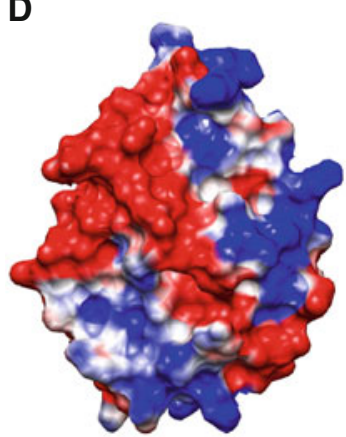

cytochrome $c$ reveals a prevalently charged surface, which

Therefore, a mechanism for the electron transfer reaction in $W$. succinogenes $\mathrm{N}_{2} \mathrm{OR}$ can be proposed in which the tations. In particular, the W. succinogenes $\mathrm{N}_{2} \mathrm{OR}$ might (Fig. 7b), which is proposed to be a periplasmic cytochrome $c$ [28]. After the reduction of the $c$-type-heme-containing tion" in which the heme group assumes the appropriate ori-

In conclusion, this docking study predicted the interacting geometries between $\mathrm{N}_{2} \mathrm{OR}$ and its physiological electron donors. These models are corroborated by experimental data and in the case of $P$. denitrificans $\mathrm{N}_{2} \mathrm{OR}$ are in agreement with the previously proposed electron transfer

A set of well conserved residues were identified as being involved in the electron transfer pathway, suggesting the 
Fig. 7 a Proposed model for the $W$. succinogenes $\mathrm{N}_{2} \mathrm{OR}$, which has an additional C-terminal domain with a $c$-type heme. The C-terminal domain (red or pink) is shown to interact with the surface of the $\mathrm{N}_{2} \mathrm{OR}$ domain surrounding the $\mathrm{CuA}$ domain, the proposed entry site for the electron. The two copper atoms of the $\mathrm{CuA}$ center and the catalytic $\mathrm{CuZ}$ center are colored black and the $\mathrm{CuA}$ and $\mathrm{CuZ}$ domains of $\mathrm{N}_{2} \mathrm{OR}$ are colored purple and blue, respectively. b Proposed scheme for the electron transfer mechanism in $W$. succinogenes $\mathrm{N}_{2} \mathrm{OR}$. The $\mathrm{CuA}$ and $\mathrm{CuZ}$ domains are represented in purple and blue, respectively, and the

cytochrome $c$ domain is red and pink. To receive the electron from the electron donor, $W$. succinogenes $\mathrm{N}_{2} \mathrm{OR}$ is in an "open conformation"; to transfer an electron from the $c$ type heme domain to the $\mathrm{CuA}$ domain, the enzyme rearranges to a "close conformation"
A

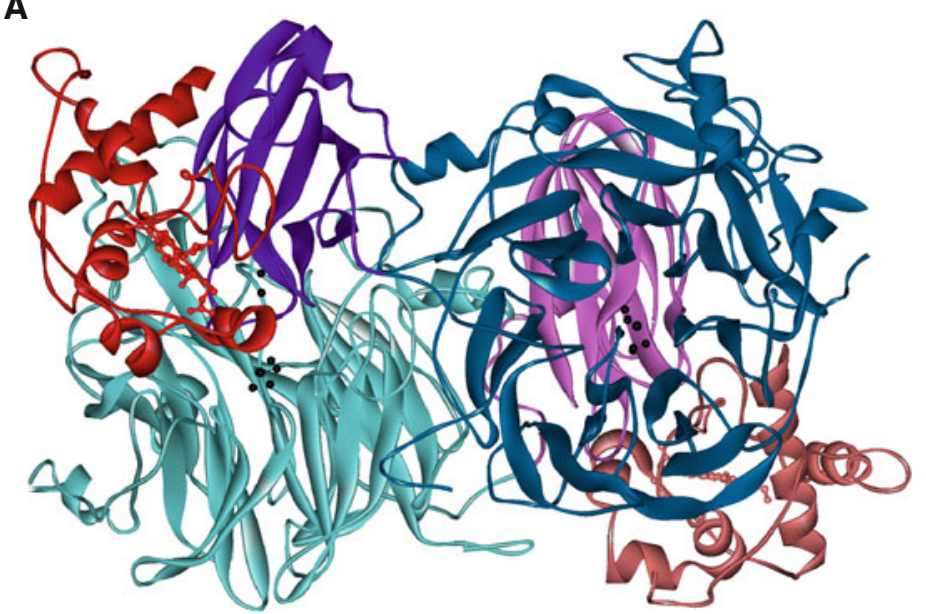

B

"open conformation"

"close conformation"

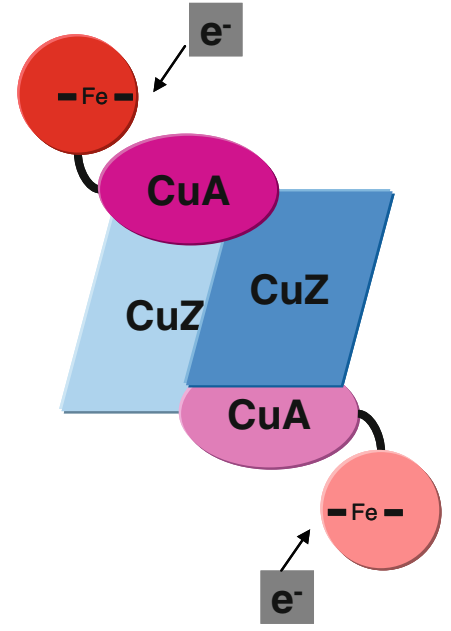

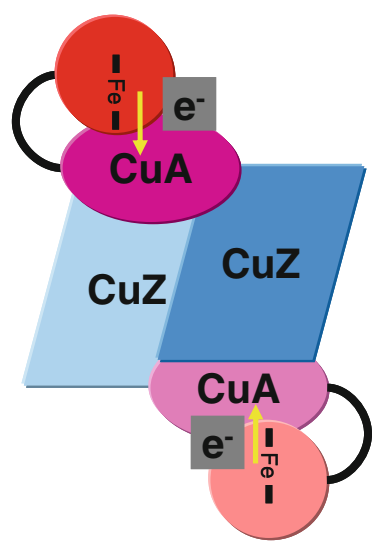

presence of a specific region in both the donor and the acceptor proteins that enables the molecular recognition, formation of the encounter complex, and efficient electron transfer. However, it was not possible to identify a single electron transfer route, and instead a patch of surface residues was identified as being instrumental for partner recognition and complex formation, and involved in the electron transfer pathway.

Moreover, the electron transfer pathway between the $\mathrm{CuA}$ center and the $\mathrm{CuZ}$ center was investigated, suggesting two alternative routes for the reduction of the catalytic center, which agree with the accepted catalytic mechanism of this enzyme: full reduction of the $\mathrm{CuZ}$ center is required prior to $\mathrm{N}_{2} \mathrm{O}$ binding.

A model structure for the W. succinogenes $\mathrm{N}_{2} \mathrm{OR}$, which has an additional $\mathrm{C}$-terminal domain containing a $c$-type heme, was proposed. This model presents the heme iron at a distance of 18-19 $\AA$ from the CuA center of the $\mathrm{N}_{2} \mathrm{OR}$ domain, forming a putative efficient electron route.
This work shows that BiGGER algorithm can be used to identify putative electron transfer partners that could be used as artificial electron donors in in vitro assays, or to propose the physiologic redox partner of an enzyme when there are several candidates in the same organism. The information presented here and the model structures can also be used as starting points for mutagenesis studies to unambiguously identify residues that are involved in electron transfer and/or partner recognition.

Acknowledgments This research was supported by Fundação para a Ciência e Tecnologia grants PTDC/QUI/64638/2006 (to I.M.) and SFRH/BD/30414/2006 (to S.D.).

\section{References}

1. Zumft WG (1997) Microbiol Mol Biol Rev 61:533-616

2. Tavares P, Pereira AS, Moura JJG, Moura I (2006) J Inorg Biochem 100:2087-2100 
3. Lo Conte L, Chothia C, Janin J (1999) J Mol Biol 285:2177-2198

4. Prudencio M, Ubbink M (2004) J Mol Recognit 17:524-539

5. Sukumar N, Chen Z-w, Ferrari D, Merli A, Rossi GL, Bellamy HD, Chistoserdov A, Davidson VL, Mathews FS (2006) Biochemistry $45: 13500-13510$

6. Moreira IS, Fernandes PA, Ramos MJ (2010) J Comput Chem $31: 317-342$

7. Palma PN, Krippahl L, Wampler JE, Moura JJG (2000) Proteins 39:372-384

8. Xu X, Schurmann P, Chung J, Hass M, Kim S, Hirasawa M, Tripathy J, Knaff D, Ubbink M (2009) J Am Chem Soc 131:17576-17582

9. Fantuzzi A, Meharenna YT, Briscoe PB, Guerlesquin F, Sadeghi SJ, Gilardi G (2009) Biochim Biophys Acta 1787:234-241

10. Almeida RM, Pauleta SR, Moura I, Moura JJG (2009) J Inorg Biochem 103:1245-1253

11. Zumft WG, Kroneck PM (2007) Adv Microb Physiol 52:107-227

12. Brown K, Tegoni M, Prudencio M, Pereira AS, Besson S, Moura JJG, Moura I, Cambillau C (2000) Nat Struct Biol 7:191-195

13. Haltia T, Brown K, Tegoni M, Cambillau C, Saraste M, Mattila K, Djinovic-Carugo K (2003) Biochem J 369:77-88

14. Paraskevopoulos K, Antonyuk SV, Sawers RG, Eady RR, Hasnain SS (2006) J Mol Biol 362:55-65

15. Winkler JR (2000) Curr Opin Chem Biol 4:192-198

16. Witt H, Malatesta F, Nicoletti F, Brunori M, Ludwig B (1998) J Biol Chem 273:5132-5136

17. Maneg O, Ludwig B, Malatesta F (2003) J Biol Chem 278:46734-46740

18. Dell'Acqua S, Pauleta SR, Monzani E, Pereira AS, Casella L, Moura JJG, Moura I (2008) Biochemistry 47:10852-10862

19. Berks BC, Baratta D, Richardson J, Ferguson SJ (1993) Eur J Biochem 212:467-476

20. Moir JWB, Ferguson SJ (1994) Microbiology 140:389-397

21. Koutny M, Kucera I, Tesarik R, Turanek J, Van Spanning RJ (1999) FEBS Lett 448:157-159

22. Rasmussen T, Brittain T, Berks BC, Watmough NJ, Thomson AJ (2005) Dalton Trans 3501-3506

23. Mattila K, Haltia T (2005) Proteins 59:708-722

24. Fujita K, Ijima F, Obara Y, Hirasawa M, Brown DE, Kohzuma T, Dooley DM (2009) J Biol Inorg Chem 14(Suppl 1):S11-S20

25. Liu MY, Liu MC, Payne WJ, Legall J (1986) J Bacteriol 166:604-608

26. Fujita K, Chan JM, Bollinger JA, Alvarez ML, Dooley DM (2007) J Inorg Biochem 101:1836-1844

27. Teraguchi S, Hollocher TC (1989) J Biol Chem 264:1972-1979

28. Zhang CS, Hollocher TC (1993) Biochim Biophys Acta 1142:253-261

29. Brown K, Nurizzo D, Besson S, Shepard W, Moura J, Moura I, Tegoni M, Cambillau C (1999) J Mol Biol 289:1017-1028

30. Benning MM, Meyer TE, Holden HM (1994) Arch Biochem Biophys 310:460-466

31. Najmudin S, Pauleta SR, Moura I, Romao MJ (2010) Acta Crystallogr Sect F Struct Biol Cryst Commun 66:627-635

32. Inoue T, Nishio N, Suzuki S, Kataoka K, Kohzuma T, Kai Y (1999) J Biol Chem 274:17845-17852

33. Bushnell GW, Louie GV, Brayer GD (1990) J Mol Biol 214:585-595

34. Mirkin N, Jaconcic J, Stojanoff V, Moreno A (2008) Proteins 70:83-92
35. Pettersen EF, Goddard TD, Huang CC, Couch GS, Greenblatt DM, Meng EC, Ferrin TE (2004) J Comput Chem 25:1605-1612

36. Betts JN, Beratan DN, Onuchic JN (1992) J Am Chem Soc 114:4043-4046

37. Regan JJ, Risser SM, Beratan DN, Onuchic JN (1993) J Phys Chem 97:13083-13088

38. Onuchic JN, Beratan DN, Winkler JR, Gray HB (1992) Annu Rev Biophys Biomol Struct 21:349-377

39. Thompson JD, Higgins DG, Gibson TJ (1994) Nucleic Acids Res 22:4673-4680

40. de Vries SJ, van Dijk ADJ, Bonvin AMJJ (2006) Proteins 63:479-489

41. Kelley LA, Sternberg MJ (2009) Nat Protoc 4:363-371

42. Bordoli L, Kiefer F, Arnold K, Benkert P, Battey J, Schwede T (2008) Nat Protoc 4:1-13

43. Prudencio M, Pereira AS, Tavares P, Besson S, Cabrito I, Brown K, Samyn B, Devreese B, Van Beeumen J, Rusnak F, Fauque G, Moura JJG, Tegoni M, Cambillau C, Moura I (2000) Biochemistry 39:3899-3907

44. Pauleta SR, Guerlesquin F, Goodhew CF, Devreese B, Van Beeumen J, Pereira AS, Moura I, Pettigrew GW (2004) Biochemistry 43:11214-11225

45. Williams PA, Fulop V, Leung YC, Chan C, Moir JW, Howlett G, Ferguson SJ, Radford SE, Hajdu J (1995) Nat Struct Biol 2:975-982

46. Kukimoto M, Nishiyama M, Ohnuki T, Turley S, Adman ET, Horinouchi S, Beppu T (1995) Protein Eng 8:153-158

47. Pelletier H, Kraut J (1992) Science 258:1748-1755

48. Pauleta SR, Cooper A, Nutley M, Errington N, Harding S, Guerlesquin F, Goodhew CF, Moura I, Moura JJG, Pettigrew GW (2004) Biochemistry 43:14566-14576

49. Pearson IV, Page MD, van Spanning RJM, Ferguson SJ (2003) J Bacteriol 185:6308-6315

50. Moir JW, Wehrfritz JM, Spiro S, Richardson DJ (1996) Biochem J 319:823-827

51. Kukimoto M, Nishiyama M, Tanokura M, Adman ET, Horinouchi S (1996) J Biol Chem 271:13680-13683

52. Kataoka K, Yamaguchi K, Kobayashi M, Mori T, Bokui N, Suzuki S (2004) J Biol Chem 279:53374-53378

53. Ghosh S, Gorelsky SI, Chen P, Cabrito I, Moura JJ, Moura I, Solomon EI (2003) J Am Chem Soc 125:15708-15709

54. Dell'Acqua S, Pauleta SR, Moura I, Moura JJG (2011) J Biol Inorg Chem 16:183-194

55. Gorelsky SI, Ghosh S, Solomon EI (2006) J Am Chem Soc 128:278-290

56. Wang K, Geren L, Zhen Y, Ma L, Ferguson-Miller S, Durham B, Millett F (2002) Biochemistry 41:2298-2304

57. Srinivasan V, Rajendran C, Sousa FL, Melo AM, Saraiva LM, Pereira MM, Santana M, Teixeira M, Michel H (2005) J Mol Biol 345:1047-1057

58. Chen ZW, Matsushita K, Yamashita T, Fujii TA, Toyama H, Adachi O, Bellamy HD, Mathews FS (2002) Structure 10:837-849

59. Benning MM, Meyer TE, Holden HM (1996) Arch Biochem Biophys 333:338-348

60. Stelter M, Melo AM, Pereira MM, Gomes CM, Hreggvidsson GO, Hjorleifsdottir S, Saraiva LM, Teixeira M, Archer M (2008) Biochemistry 47:11953-11963 